\title{
Efficiency of water application of irrigation systems based on microsprinkling in banana plantations
}

\author{
Alisson Jadavi Pereira da Silva ${ }^{*}$,, Eugênio Ferreira Coelho² ${ }^{2}$ Jarbas Honório de Miranda ${ }^{3}$
}

IInstituto Federal de Educação, Ciência e Tecnologia Baiano, Campus Senhor do Bonfim, Estrada da Igara, km 4, Zona Rural de Senhor do Bonfim - 48970-000 - Senhor do Bonfim, BA - Brasil.

2Embrapa Mandioca e Fruticultura Tropical, R. Embrapa, $s / n$ - 44380-000 - Cruz das Almas, BA - Brasil.

${ }^{3} U S P / E S A L Q$ - Depto. de Ciências Exatas, Av. Pádua Dias, 11 - 13418-900 - Piracicaba, SP - Brasil

*Corresponding author <alissonagr@gmail.com>

Edited by: José Euclides Stipp Paterniani
ABSTRACT: Further food production may be limited by the reduced availability of water resources. Since irrigated agriculture is the productive sector that presents a higher demand of water, this sector has been under intense pressure in order to ensure food production with improved efficiency of water use. This study aimed to use the Time Domain Reflectometry (TDR) technique to measure percolation losses and to determine water application efficiency of banana (Musa spp.) trees using microsprinkler irrigation systems. Three systems were studied: (i) one $32 \mathrm{~L} \mathrm{~h}^{-1}$ microsprinkler for four plants; (ii) one $60 \mathrm{~L} \mathrm{~h}^{-1}$ microsprinkler for four plants; and (iii) one $60 \mathrm{~L}$ $\mathrm{h}^{-1}$ microsprinkler for two plants. Systems that replace water to the soil with the lowest variation of infiltrated water depths at different distances from plant pseudostem were the most efficient. The water application efficiency of microsprinkler irrigation systems using the (i), (ii), and (iii) microsprinkler systems were $85 \%, 80 \%$ and $90 \%$ respectively.

Keywords: TDR, Musa spp., root distribution, irrigation management

Received October 17, 2011

Accepted January 22, 2013

\section{Introduction}

The increased growth of human population, the endless deforestation and the inefficient use of water in productive sectors have been reducing the availability of water resources (Sophocleous, 2004). Improvement of efficiency of water use for food production has been necessary due to the fact that agriculture is the productive sector with the highest demand for water (Howell, 2001). Thus, studies involving the total efficiency of water use in agriculture should be considered (Hsiao et al., 2007) giving priority to the production of crops susceptible to water stress. This is the case of the banana crop (Musa spp), that requires an appropriate supply of water throughout the crop cycle (Akinro et al., 2012). Water application efficiency can be defined as the ratio between the amount of water retained in the root zone of the plant and the amount of applied irrigation water (Hsiao et al., 2007). According to Howell (2008), water application efficiency has not been studied in depth, due to the difficulty in establishing some parameters that are necessary for the study. The main difficulty is the calculation of the flow of water below the root zone of the crop (percolation) that requires detailed monitoring (Koumanov et al., 2006).

Percolation below root zone has also been the major difficulty in using the soil water balance for crop evapotranspiration estimates (Hutmacher et al., 1994). Knowledge of percolation losses is also important for the environment, because it is related to ion transport to groundwater. For practical conditions, the soil water balance relies in the use of the Darcy-Buckingham equation,

\$Present Address: Embrapa Mandioca e Fruticultura Tropical, R. Embrapa, $\mathrm{s} / \mathrm{n}$ - 44380-000 - Cruz das Almas, BA - Brasil. where unsaturated hydraulic conductivity is related to average water content between an interval of time. The unsaturated soil hydraulic conductivity has been a limitation for flow calculation. Therefore, alternatives are necessary for calculating percolation without using the unsaturated hydraulic conductivity. Heimovaara et al. (2004) indicate the Time Domain Reflectometry (TDR) as a standard technique for studies that involve processes of time and space distribution of water in the soil. The TDR has high precision, automation potential, and allows the assessment of water flow in porous media. Many authors have been making use of this technique in studies involving these processes (Silva et al., 2009; Jensen et al., 2010; Souza and Folegatti, 2010; Hutton and Loveys, 2011).

Despite the general high emission uniformity of micro-sprinkler systems, there is a concern about the non-uniform water distribution around the emitter for banana crop irrigation. Nevertheless, studies with different types of micro-sprinklers have shown a uniform soil water distribution in the root zone indicating that this low application uniformity does not necessarily affect the spatial root distribution and root water uptake (Bassoi et al., 2003; Alves Júnior et al., 2012).

Through field essays, this research was carried out with the objectives: (i) to use the TDR technique for measuring water losses below banana root zone irrigated by microsprinkler systems and (ii) to determine water application efficiency of microsprinkler irrigation systems of different flow rates for the banana crop.

\section{Materials and Methods}

The experiment was conducted in Cruz das Almas, State of Bahia, Brazil (1248' S; 3906' W; 225 m a.s.1.), 
where the average annual rainfall is $1,143 \mathrm{~mm}$ (Almeida, 2004). The crop was BRS Tropical banana, spaced $3.0 \times$ $2.5 \mathrm{~m}$, during the production phase of its first cycle (Jan., 2006). The soil of the experimental site was a Latossolo Amarelo (EMBRAPA, 1997) or Xanthic Ferralsol (IUSS Working Group WRB, 2006), with physical properties presented in Table 1.

Three microsprinkler irrigation systems were evaluated: $\mathrm{T} 1$ - one microsprinkler of $32 \mathrm{~L} \mathrm{~h}^{-1}$ for four plants with one lateral line between two plant rows; T2 - one microsprinkler of $60 \mathrm{~L} \mathrm{~h}^{-1}$ for four plants, with one lateral line between two plant rows, and T3 - one microsprinkler of $60 \mathrm{~L} \mathrm{~h}^{-1}$ for two plants with a lateral line near plant row. The experimental unit was composed by four plant rows with the lateral irrigation line between the two central ones. The measurements were taken in the space between four plants around an emitter in the center of the unit. Data were collected during five days in each treatment.

The frequency of irrigation was daily and the volume of water applied per plant was common to all treatments, calculated based on the recommendations made by Keller and Bliesner (1990), with the crop evapotranspiration considering the crop coefficients suggested by Doorembos and Kassam (1984). Fertilization was made as recommended by Borges et al. (2000), with nitrogen, potassium and phosphorus being applied through irrigation water.

Soil water content was monitored using a data acquisition system composed by three-rod probes, a TDR, multiplexers and a data logger (Figure 1). The TDR probes were inserted horizontally at locations represented by distances $(\mathrm{r})$ and depths $(\mathrm{z})$, in a grid of $0.20 \mathrm{~m} \times$ $0.20 \mathrm{~m}$ of a vertical plane that was radial to the plant, having the origin at the soil surface near to the plant and limits of $\mathrm{r}=1.0 \mathrm{~m}$ and $\mathrm{z}=1.0 \mathrm{~m}$.

The TDR probes were made with rods of $0.10 \mathrm{~m}$ length and $0.017 \mathrm{~m}$ apart each other. The calibration equation was:

$\theta=6.438 \varepsilon^{3}-5.5246 \varepsilon^{2}+2.0373 \varepsilon-0.0745$

where: $\theta$ is the soil water content $\left(\mathrm{m}^{3} \mathrm{~m}^{-3}\right) ; \varepsilon$ is the bulk dielectric constant of the soil.
After the TDR probes were installed, samples of $0.005 \mathrm{~m}^{3}$ of soil and roots were collected for root distribution evaluation. Roots were separated from the soil by washing and then digitalized by scanning according to Coelho and Or (1998). Root length "Lr" (cm) was obtained through the Rootedge software (Kaspar and Ewing, 1997). Root length density (RLD) was calculated by equation (2):

$\operatorname{RLD}=\frac{\mathrm{L}_{\mathrm{r}}}{\mathrm{V}_{\mathrm{r}}}$

where $V_{r}$ is the volume of sample $\left(\mathrm{m}^{3}\right)$.

Soil water monitoring started 30 days after probe installation. The measurements were made in each soil sample in intervals of ten minutes during five days. The calculations on the infiltrated water depth (LTI) after irrigation and also the extracted water from the system (LTE) were based on soil water content data at specific moments: (i) immediately before the irrigation event on day (k); (ii) when the irrigation water has reached the deepest position monitored in the plane $(k+1)$, which was characterized by confirmation of the increase in values of soil water content of the probe at the $0.9 \mathrm{~m}$ depth; (iii) before the next irrigation $(\mathrm{k}+2)$, as shown in Figure 2 .

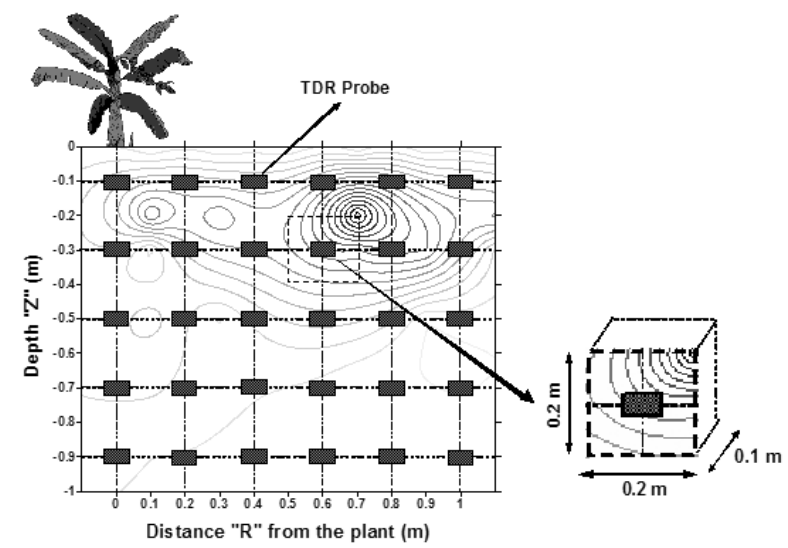

Figure 1 - Monitoring soil water content in the region of the root system of the banana tree.

Table 1 - Physical properties of the soil.

\begin{tabular}{lcccc}
\hline \multirow{2}{*}{ Characteristics } & & \multicolumn{2}{c}{ Depth $(\mathrm{m})$} \\
\hline & & $0-0.2$ & $0.2-0.4$ & $0.4-0.6$ \\
\hline \multirow{2}{*}{$\begin{array}{l}\text { Granulometric Composition } \\
\left(\mathrm{g} \mathrm{kg}^{-1}\right)\end{array}$} & Total Sand & 577 & 517 & 493 \\
& Silt & 99 & 89 & 133 \\
\hline Texture Classification & Clay & 324 & 394 & 374 \\
\hline Porosity (\%) & & Sandy clay loam & Sandy clay loam & Sandy clay loam \\
\hline Bulk density & Macro & 13.34 & 11.91 & 11.92 \\
\hline 10 Kpa water content $\left(\mathrm{m}^{3} \mathrm{~m}^{-3}\right)$ & Micro & 26.34 & 28.44 & 26.14 \\
1500 Kpa water content $\left(\mathrm{m}^{3} \mathrm{~m}^{-3}\right)$ & & 1.50 & 1.48 & 1.52 \\
\hline Hydraulic Conductivity & $\left(\mathrm{kg} \mathrm{dm}^{-3}\right)$ & 0.2106 & 0.2400 & 0.2195 \\
\hline
\end{tabular}




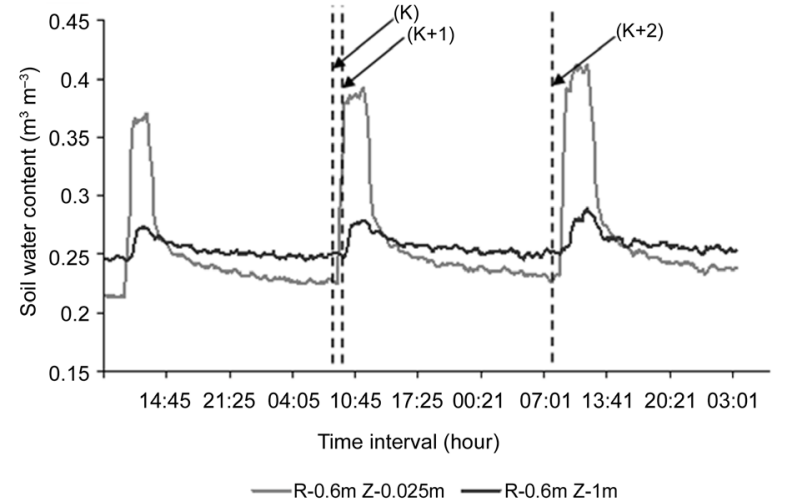

Figure 2 - Soil water content at times immediately before the irrigation event on day ( $k$ ), when the irrigation water has reached the deepest position monitored in the plane $(k+1)$ and before the next irrigation $(k+2)$ were used for the establishment of infiltrated water depth (LTI) and extracted water depth (LTE).

The difference between the soil water content measured after irrigation $\left(\theta^{\mathrm{k}+1}\right)$ and immediately before irrigation $\left(\theta^{\mathrm{k}}\right)$, allowed the establishment of the water depth that infiltrated in at time $(\mathrm{k}+1)-(\mathrm{k})$, at distance " $\mathrm{r}$ " of the grid from the surface $(z=0)$ to the depth where the deepest probe was located $(z=L)$, as in Equation (3):

$\mathrm{LTI}=\int_{0}^{\mathrm{L}}\left[\theta^{k+1}(\mathrm{z})-\theta^{k}(\mathrm{z})\right] \mathrm{dz}$

where $\theta^{k+1}(z)$ is the soil water content after irrigation at a location $\mathrm{z}(\mathrm{mm})$; and $\theta^{k}(z)$ is the soil water content before irrigation at a location $\mathrm{z}(\mathrm{mm})$.

The evaluation of the average water depth in the control root volume of the banana tree can be made by applying Equation (4).

$\mathrm{LTI}_{\mathrm{m}}=\frac{\sum_{\mathrm{i}=1}^{\mathrm{n}} \mathrm{LTI}}{\mathrm{n}}$

where $\mathrm{LTI}_{\mathrm{m}}$ - is the average of total infiltrated water depth $(\mathrm{mm})$; LTI is the infiltrated water depth at each position " $\mathrm{r}$ " of the grid $(\mathrm{mm}) ; \mathrm{n}$ is the number of points $(\mathrm{r})$.

The difference between the measurements of soil water content at the times $(\mathrm{k}+1)$ and $(\mathrm{k}+2)$, at any " $\mathrm{r}$ " of the grid, allowed the establishment of the water depth extracted at distance $r$, as shown in Equation (5):

LTE $=\int_{0}^{\mathrm{L}} \theta^{k+1}(z)-\theta^{k+2}(z) d z$

where LTE is the water depth extracted in each position " $\mathrm{r}$ " of the grid $(\mathrm{mm}) ; \theta^{k+1}(z)$ is the soil water content at time $(\mathrm{k}+1)$ at depth " $\mathrm{z}^{\prime \prime}(\mathrm{mm}) ; \theta^{k+2}(z)$ is the soil water content at time $(\mathrm{k}+2)$ at depth " $\mathrm{z}$ " $(\mathrm{mm})$.

The average of total extracted water depth was obtained by Equation (6) below:

$L T E_{m}=\frac{\sum_{i=1}^{n} L T E}{n}$
In order to relate soil water and plant root distribution, the effective root depth was assumed as that concentrating up to $80 \%$ of the total root length. Percolation loss can be calculated for each distance " $r$ " from plant, located just below the effective depth of the roots, by equation (7):

$D P=\int_{k+1}^{k+2} q d t$

where $\mathrm{q}$ is the flow of water in the soil $\left(\mathrm{mm} \mathrm{h}^{-1}\right)$, which is calculated by using equation (8):

$\mathrm{q}=\frac{\theta^{\mathrm{k}}-\theta^{\mathrm{k}+\mathrm{I}^{\mathrm{j}}}}{\Delta \mathrm{t}} \cdot 1$

where 1 is the length of the layer where probes were inserted $(\mathrm{cm}) ; \Delta \mathrm{t}$ is the time interval $(1 \mathrm{~h}) ; \theta^{\mathrm{k}}$ is the soil water content at time $k\left(\mathrm{~mm} \mathrm{~cm}^{-1}\right) ; \theta^{\mathrm{k}+1}$ is the soil water content at the time $k+1\left(\mathrm{~mm} \mathrm{~cm}^{-1}\right)$

In this way, the average loss through percolation in the profile from the plant along the $\mathrm{n}$ distances from it may be calculated by Equation (9):

$\mathrm{DP}_{\mathrm{m}}=\frac{\sum_{\mathrm{R}=1}^{\mathrm{n}} \mathrm{DP}}{\mathrm{n}}$

The values of $\mathrm{DP}_{\mathrm{m}}$ calculated for different intervals after the beginning of irrigation (A.I) for treatments $\mathrm{T} 1, \mathrm{~T} 2$ and $\mathrm{T} 3$ were compared by using the LSD test $(p$ $<0.05)$.

The average efficiency of the application of water $\left(E_{a}\right)$ was calculated by the use of Equation (10):

$\mathrm{E}_{\mathrm{a}}=\frac{\mathrm{LTE}_{\mathrm{m}}-\mathrm{DP}_{\mathrm{m}}}{\mathrm{LTI}_{\mathrm{m}}}$

\section{Results and Discussion}

There was a reduction in the value of saturated hydraulic conductivity and an increase in soil water retention at the depth of 0.2-0.4 m, confirming the heterogeneity of the soil profile and consistent with reported data (Sobral et al., 2009; Fernandes et al., 2011). The larger precipitations have always been recorded away from the plant and close to the microsprinklers (Figure 3 ). As an example, there were records of precipitation levels of $4.58 \mathrm{~mm}, 10.2 \mathrm{~mm}$ and $5.0 \mathrm{~mm}$ at a distance $\mathrm{r}$ $=1 \mathrm{~m}$ for systems $\mathrm{T} 1, \mathrm{~T} 2$ and $\mathrm{T} 3$, respectively, while the precipitation levels at a distance of $\mathrm{r}=0.2 \mathrm{~m}$ were 1.05 $\mathrm{mm}, 0 \mathrm{~mm}$ and 2,0 $\mathrm{mm}$ for the systems T1, T2 and T3, respectively (Figure 3).

The water distribution in the soil just after the end of an irrigation event was multidimensional and non-uniform and soil water availability became larger as the distance from the plant increased towards the microsprinkler, coinciding with the region where the largest water depth applied by the microsprinklers was collected (Figure 4). The average water availability in the effective depth of the banana roots were $52 \%, 50 \%$, 

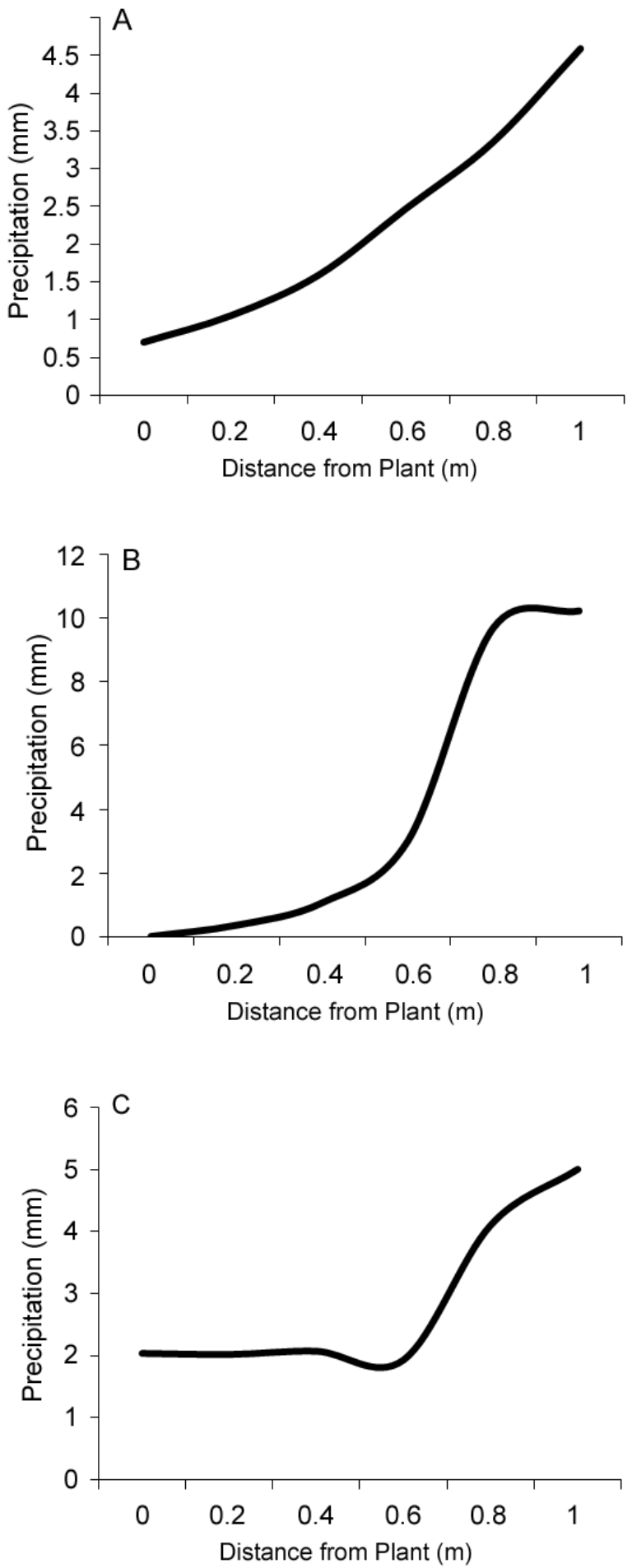

Figure 3 - Precipitation as a function of the distance of the plant going towards the microsprinkler, with regard to the systems with one microsprinkler of $32 \mathrm{~L} \mathrm{~h}^{-1}$ for four plants with one lateral line between two rows of plants (A); one microsprinkler of $60 \mathrm{~L} \mathrm{~h}^{-1}$ for four plants, with one lateral line between two rows of plants $(B)$, and one microsprinkler of $60 \mathrm{~L} \mathrm{~h}^{-1}$ for two plants with a lateral line near the row of plants $(C)$.
$60 \%$ at a distance of $\mathrm{r}=0.2 \mathrm{~m}$ and $90 \%, 90 \%, 90 \%$ at a distance of $\mathrm{r}=1.0 \mathrm{~m}$ for systems $\mathrm{T} 1, \mathrm{~T} 2$ and $\mathrm{T} 3$, respectively.

The distribution of root length density in the soil profile and also the percentage of total root length of the soil profile at horizontal distances towards the microsprinkler $(\mathrm{r})$ and depths $(\mathrm{z})$, are shown in Figures 5 and 6, respectively. The effective depth of the roots of the plants irrigated by the systems consisting of a microsprinkler of $32 \mathrm{~L} \mathrm{~h}^{-1}$ for four plants, a microsprinkler of $60 \mathrm{~L} \mathrm{~h}^{-1}$ for four plants and also a microsprinkler of $60 \mathrm{~L} \mathrm{~h}^{-1}$ for two plants, took place up to $0.5 \mathrm{~m}, 0.5 \mathrm{~m}$ and $0.6 \mathrm{~m}$ respectively. The root distribution of banana plants (Figures 5A, 5B and $5 \mathrm{C}$ ) for systems T1, T2 and T3 agrees with the distribution of water availability, this being evident in the root water extraction distribution, which was also observed by Ahmadi et al. (2011); Ceccon et al. (2011); Sokalska et al. (2009); Mmolawa and Or (2000). Silva et al. (2009) determined root distribution and water application efficiency for BRS Tropical banana irrigated by different drip systems in the same soil and local conditions of this study during the production phase.

Despite the similarity of the effective root depth and distance in both studies, some differences were observed in the effective water extraction zones indicating the effect of soil water distribution as a consequence of the irrigation systems on water extraction by banana. As observed by Andreu et al. (1997), the zones of water extraction were influenced by the type of emitters around the plant. Root distribution might be a strong indication of the potential root water extraction; however we did not observe a relationship between water extraction and root concentration in our study.

Water extraction is strongly dependent on spacetime variations of soil water availability. The larger root densities took place at distances from plant of $0-0.2 \mathrm{~m}$, as verified in T1. However, the soil water distribution for microsprinkler irrigation provided larger values of water availability at $0.8 \mathrm{~m}$ from plant and larger values of water extraction were found at the same distance from the plant because of that. There was percolation loss in all treatments (Table 2). The results show the average values of percolated water depths at different moments after the beginning of irrigation (A.I.). The comparison of the means for the treatments at specific times, the values of percolated water depths varied $(p<0.05)$ according to the configurations of the microsprinkling irrigation systems, from $1 \mathrm{~h}$ after the start of irrigation and $2 \mathrm{~h}$ and $4 \mathrm{~h}$ after that the means were different and only higher in the case of treatment T2. $64 \%$ of the total percolation loss during the time interval (Table 2) occurred at the first four hours which indicates the quick soil water redistribution.

There were no differences $(p>0.05)$ in the average percolated water depth values between $6 \mathrm{~h}$ and $14 \mathrm{~h}$ after beginning of the irrigation. The estimate of percolation under field conditions has been still considered a 

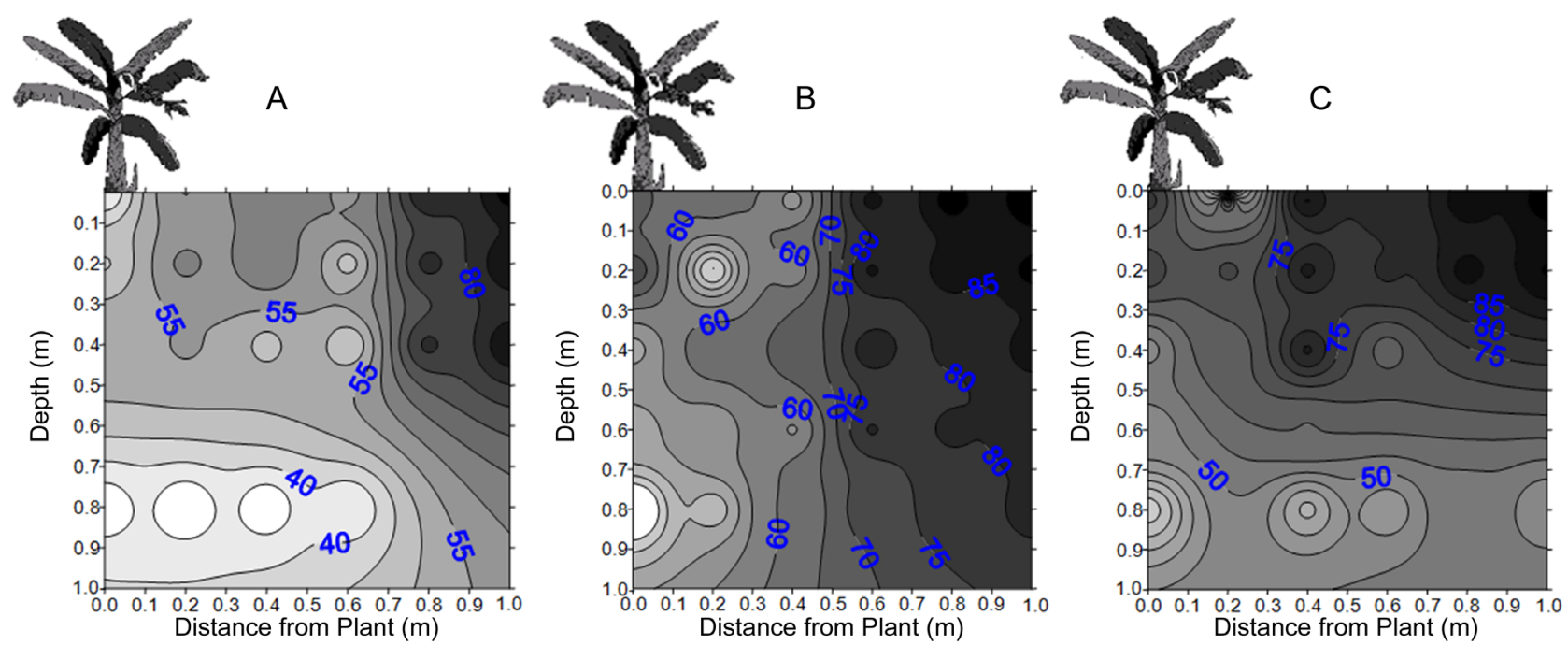

Figure 4 - Percent available water content available, starting out from the plant and moving towards the emitter, for systems with one microsprinkler of $32 \mathrm{~L} \mathrm{~h}^{-1}$ for four plants with one lateral line between two rows of plants (A); one microsprinkler of $60 \mathrm{~L} \mathrm{~h}^{-1}$ for four plants, with one lateral line between two rows of plants $(B)$, and one microsprinkler of $60 \mathrm{~L} \mathrm{~h}^{-1}$ for two plants with a lateral line near the row of plants (C).
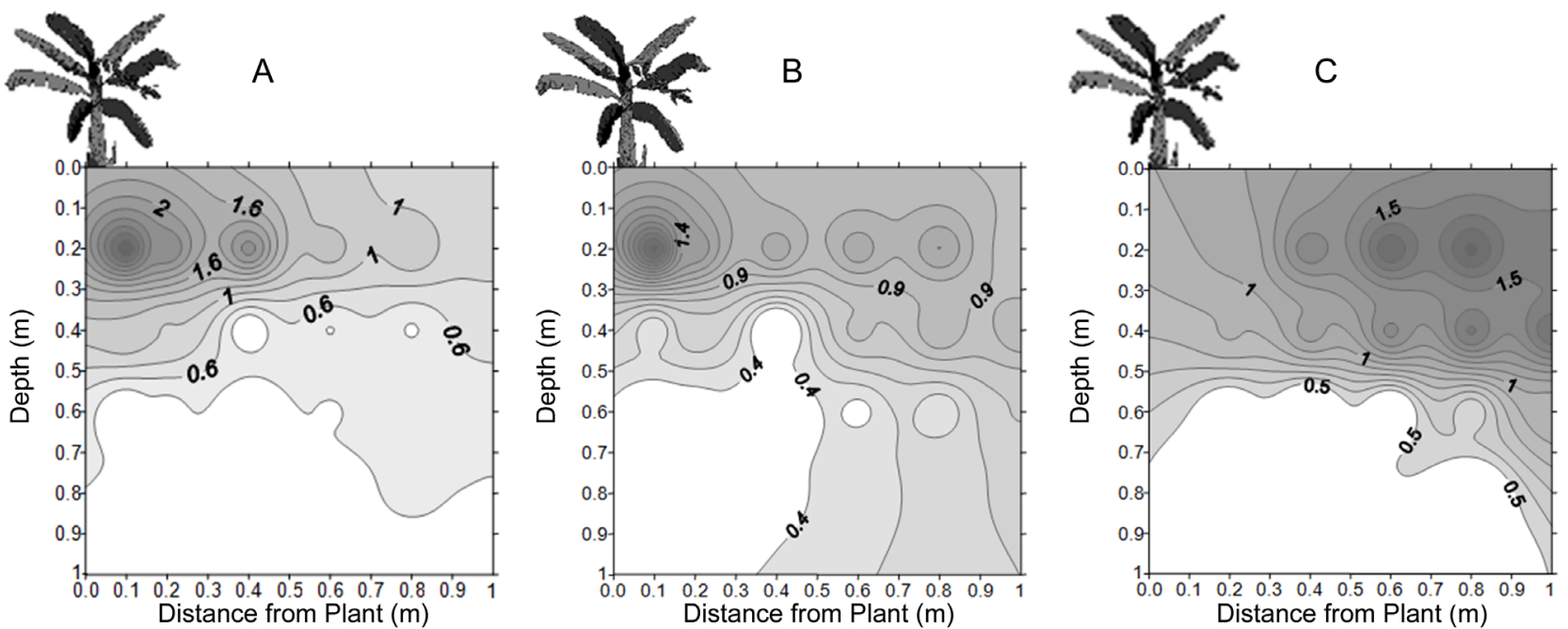

Figure 5 - Isolines of root length $\left(\mathrm{m} \mathrm{m}^{-3}\right.$ ) of the banana for systems with one microsprinkler of $32 \mathrm{~L} \mathrm{~h}^{-1}$ for four plants with one lateral line between two rows of plants (a); one microsprinkler of $60 \mathrm{~L} \mathrm{~h}^{-1}$ for four plants, with one lateral line between two rows of plants (b), and one microsprinkler of $60 \mathrm{~L} \mathrm{~h}^{-1}$ for two plants with a lateral line near the row of plants (c).

challenge (Selle et al., 2011; Baram et al., 2012). DarcyBuckingham equation enables to quantify vertical water flow in non saturated soils (Jiménez-Martíneza et al., 2009; Ji et al., 2007; Skaggs et al., 2006), however some difficulties in its use are claimed by Reichardt \& Timm (2012), mainly due to the exponential function that can be fitted to data. This fact shows large errors for small variations in soil water content (Mubarak et al., 2010). Therefore, it is necessary to evaluate soil water content variations in the root zone for short time intervals in or- der to obtain the volume of water lost by percolation in the field. This is necessary due to the quick soil water redistribution and percolation in the soil profile under microsprinkler irrigation. The percolation may not be estimated correctly for large time intervals.

In system $\mathrm{T} 1$, the smaller infiltrated water depths are in the region between the pseudostem of the plant out to a distance of $0.4 \mathrm{~m}$, which concentrates $48 \%$ of the total root length. In this region, almost no loss of water through percolation has been recorded. As from a 

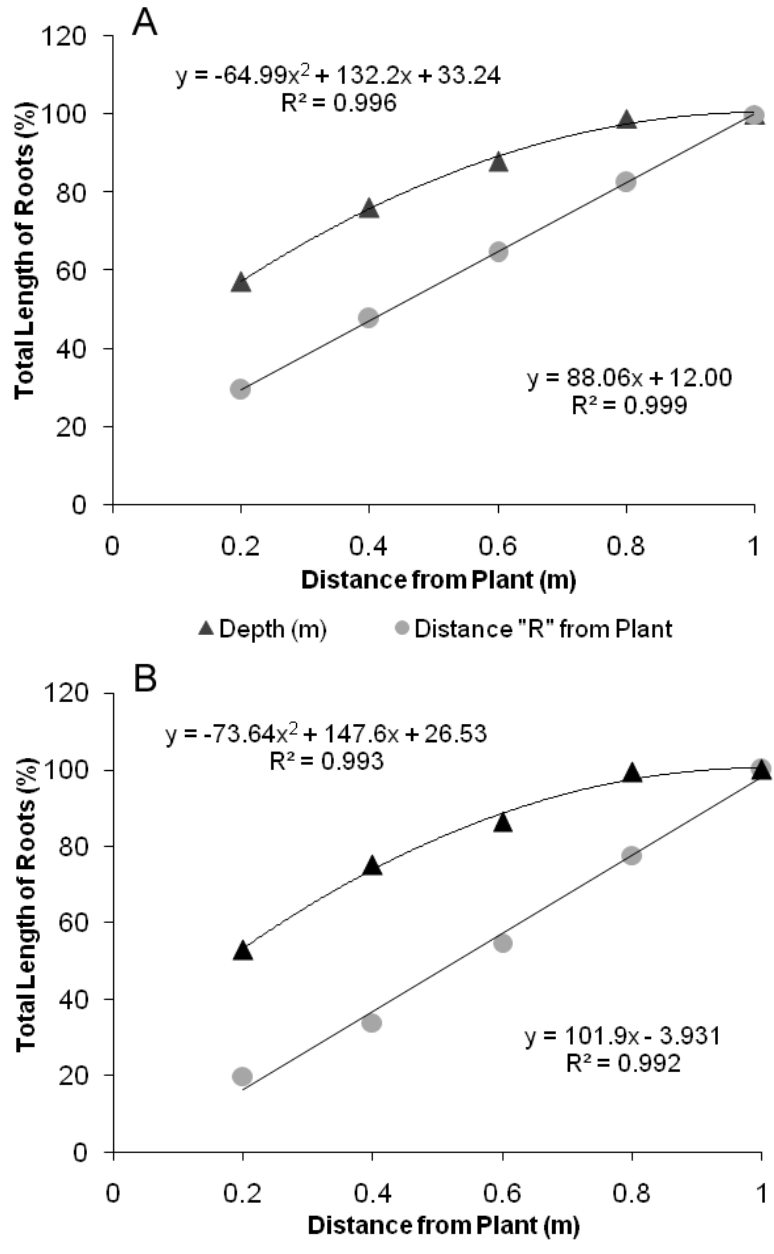

- Distance "R" from Plant

$\triangle$ Depth "Z"

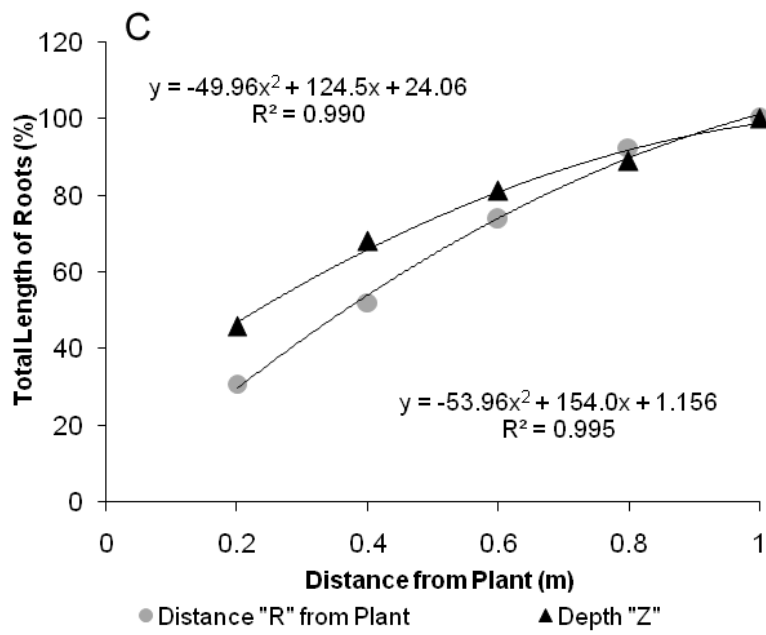

Figure 6 - Percentages of total root length in the soil profile at horizontal distances between plant and microsprinkler $(r)$ and depths (z) for systems with one microsprinkler of $32 \mathrm{~L} \mathrm{~h}^{-1}$ for four plants with one lateral line between two rows of plants $(A)$; one microsprinkler of $60 \mathrm{~L} \mathrm{~h}^{-1}$ for four plants, with one lateral line between two rows of plants (B), and one microsprinkler of $60 \mathrm{~L} \mathrm{~h}^{-1}$ for two plants with a lateral line near the row of plants (C).
Table 2 - Average percolation values at different times after irrigation.

\begin{tabular}{llcc}
\hline \multirow{2}{*}{ Times } & \multicolumn{3}{c}{ Treatments } \\
\cline { 2 - 4 } & \multicolumn{1}{c}{ T1 } & T2 & T3 \\
\cline { 2 - 4 } $1 \mathrm{~h}$ & $0.1878 \mathrm{ab}$ & $0.2531 \mathrm{~b}$ & $0.1097 \mathrm{a}$ \\
$2 \mathrm{~h}$ & $0.1165 \mathrm{a}$ & $0.4960 \mathrm{~b}$ & $0.1175 \mathrm{a}$ \\
$4 \mathrm{~h}$ & $0.1147 \mathrm{a}$ & $0.2416 \mathrm{~b}$ & $0.0968 \mathrm{a}$ \\
$6 \mathrm{~h}$ & $0.1015 \mathrm{a}$ & $0.1024 \mathrm{a}$ & $0.1156 \mathrm{a}$ \\
$8 \mathrm{~h}$ & $0.0871 \mathrm{a}$ & $0.0752 \mathrm{a}$ & $0.0953 \mathrm{a}$ \\
$10 \mathrm{~h}$ & $0.0344 \mathrm{a}$ & $0.0970 \mathrm{a}$ & $0.0419 \mathrm{a}$ \\
$12 \mathrm{~h}$ & $0.0117 \mathrm{a}$ & $0.0136 \mathrm{a}$ & $0.0253 \mathrm{a}$ \\
$14 \mathrm{~h}$ & $0.0056 \mathrm{a}$ & $0.0009 \mathrm{a}$ & $0.0118 \mathrm{a}$ \\
\hline
\end{tabular}

${ }^{*}$ Values followed by the same letter in the rows do not show differences (t test (LSD), $p<0.05$ ).

T1 is the treatment irrigated by one microsprinkler of $32 \mathrm{~L} \mathrm{~h}^{-1}$ for four plants with one lateral line between two plant rows, T2 by one microsprinkler of $60 \mathrm{~L}$ $\mathrm{h}^{-1}$ for four plants, with one lateral line between two plant rows, and T3 by one microsprinkler of $60 \mathrm{~L} \mathrm{~h}^{-1}$ for two plants with a lateral line near plant row.

distance of $0.8 \mathrm{~m}$, there was a considerable loss of percolation water, reaching $2.1 \mathrm{~mm}$ at $\mathrm{r}=1 \mathrm{~m}$ (Figure 7). On average, the percolation water depth $\left(\mathrm{DP}_{\mathrm{m}}\right)$ in the $\mathrm{T} 1$ system was $1.055 \mathrm{~mm}$, and the ratio between the quantity of water applied by this system and the water that remained in the region around the root system of the plant was 0.8501 , which means that water application efficiency (Ea) remained at $85 \%$ (Table 3).

In T2 there has been the least uniform water distribution at different horizontal distances between plant and microsprinkler. LTI at a distance of $0.2 \mathrm{~m}$ was 0.9 $\mathrm{mm}$ on average, while at a distance of $1 \mathrm{~m}$ itreached 9.2 $\mathrm{mm}$. The percolation losses at distances of $0.6 \mathrm{~m}, 0.8 \mathrm{~m}$ and $1 \mathrm{~m}$ were $1.9 \mathrm{~mm}, 2.6 \mathrm{~mm}$ and $2.4 \mathrm{~mm}$, respectively (Figure 8). Despite the horizontal development of the roots of banana trees subjected to this system, the highest losses of water by percolation were observed $\left(\mathrm{DP}_{\mathrm{m}}=\right.$ $1.9 \mathrm{~mm}$ ) with water application efficiency of $80 \%$.

The lowest differences in the LTI values for different distances from the plant $(\mathrm{r})$ were obtained in the system using a microsprinkler of $60 \mathrm{~L} \mathrm{~h}^{-1}$ for two plants (Figure 9). The $\mathrm{DP}_{\mathrm{m}}$ value for this system was the lowest among all $(0.96 \mathrm{~mm})$ and the efficiency of application of water was the highest, $90 \%$. Koumanov et al. (1994) worked with 25 neutron probe access tubes to evaluate daily variations of soil water content in the rhizosphere of an almond crop irrigated by $41 \mathrm{~L} \mathrm{~h}^{-1}$ microsprinklers with effective root depth in the layer $0-0.30 \mathrm{~m}$. The authors found values of application efficiency ranging from 73 to $79 \%$, but they disregarded percolation and considered evaporation as the main cause for water loss in irrigation.

There is greater extraction of water by the plant with the increased uniformity of the water distributed in the soil. Larger application efficiency was found where smaller variations of LTI at the different distances from the pseudostem were observed. On the other hand, larger variation of LTI at different distanc- 


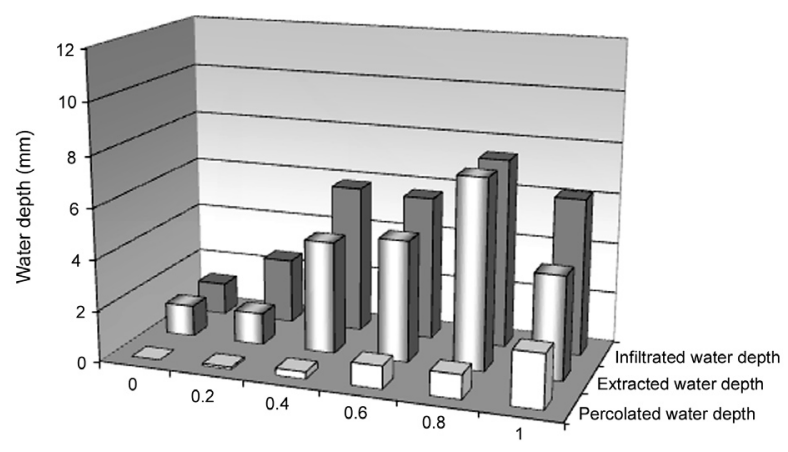

Distance from plant $(m)$

$\square$ Percolated water depth $\quad$ Q Extracted water depth $\quad$ Infiltrated water depth

Figure 7 - Infiltrated, extracted and percolated water depths in the soil profile irrigated by microsprinkler system of $32 \mathrm{~L} \mathrm{~h}^{-1}$ for four plants (T1).

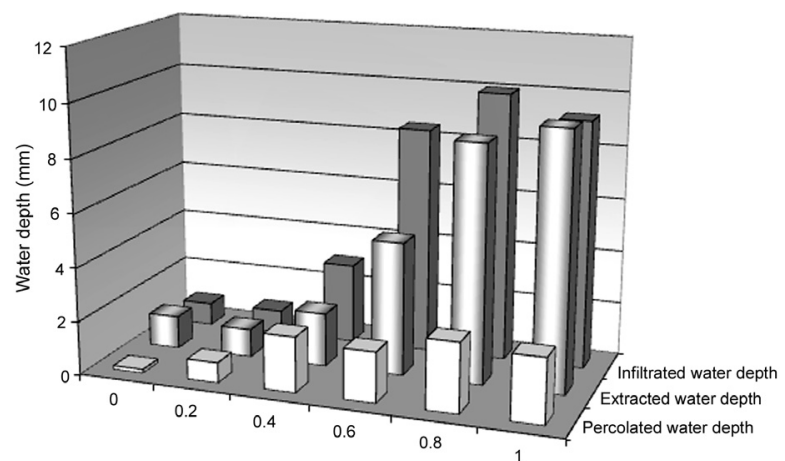

Distance from plant $(\mathrm{m})$

口Percolated water depth $\quad$ Exxtracted water depth $\quad$ Infiltrated water depth

Figure 8 - Infiltrated, extracted and percolated water depths in the soil profile irrigated by microsprinkler of $60 \mathrm{~L} \mathrm{~h}^{-1}$ for four plants (T2).

Table 3 - Components of the calculation of water application efficiency (Ea).

\begin{tabular}{llcllll}
\hline \multicolumn{5}{c}{ Average water depth (mm) } & & \\
\cline { 1 - 4 } & $\begin{array}{c}\text { Infiltrated water in } \\
\text { profile }\end{array}$ & $\begin{array}{c}\text { Retained in the } \\
\text { plant } \\
\text { root zone }\end{array}$ & $\begin{array}{c}\text { Perco- } \\
\text { lated }\end{array}$ & LTE & $\begin{array}{c}\text { Ea } \\
(\%)\end{array}$ \\
\hline T1 & 4.67 & 3.97 & 1.055 & 5.0 & 85 \\
$\mathrm{~T} 2$ & 5.56 & 4.43 & 1.9 & 6.3 & 80 \\
T3 & 3.108 & 2.783 & 0.96 & 3.7 & 90 \\
\hline
\end{tabular}

LTE: Extracted water depth

es from pseudostem corresponded to smaller water application efficiencies. Therefore, the surface water distribution by the microsprinkler has strong influence on plant water extraction. This is in agreement with

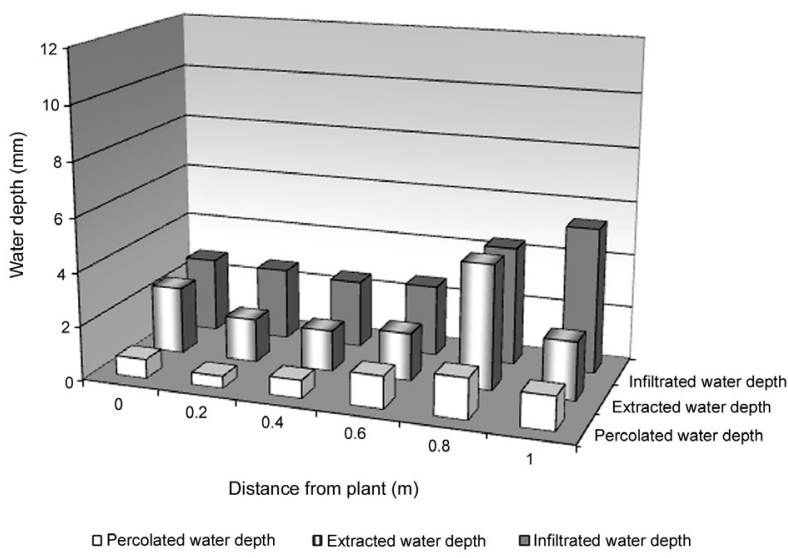

Figure 9 - Infiltrated, extracted and percolated water depth in the soil profile irrigated by microsprinkler of $60 \mathrm{~L} \mathrm{~h}^{-1}$ for two plants (T3).

the findings of Clothier and Green (1994) and Green et al. (2006). For the same volume ofapplied water, lower values of $\mathrm{DP}_{\mathrm{m}}$ were obtained as the distribution of water in the soil became more uniform, and as a result the LTE $_{\mathrm{m}}$ became higher, improving water application efficiency.

It is concluded that for the same volume of applied water, as the uniformity of water distribution in the systems increases, there is a reduction in percolation, an increase in plant water extraction, and also an increase in the water application efficiency.

\section{References}

Ahmadi, S.H.; Plauborg, F.; Andersen, M.N.; Sepaskhah, A.R.; Jensen, C.R.; Hansen, S. 2011. Effects of irrigation strategies and soils on field grown potatoes: root distribution. Agricultural Water Management 98: $1280-1290$.

Akinro, A.O.; Olufayo, A.A.; Oguntunde, P.G. 2012. Crop water productivity of plantain (Musa Sp) in a humid tropical environment. Journal of Engineering Science and Technology Review 5: 19-25.

Alves Júnior, J.; Bandaranayake, W.; Parsons, L. R.; Evangelista, A. W. P. 2012. Citrus root distribution under water stress grown in Sandy soil of central Florida. Engenharia Agrícola 32: 1109 -1115 .

Andreu, L.; Hopmans, J.W.; Schwank, L.J. 1997. Spatial and temporal distribution of soil water balance for a drip-irrigated almond tree. Agricultural Water Management 35: 123-146.

Baram, S.; Kurtzman, D.; Dahan, O. 2012. Water percolation through a clayey vadose zone. Journal of Hydrology 424-425, $165-171$

Bassoi, L.H.; Hopmans, J.W.; Jorge, L.A.C.; Alencar, C.M.; Silva, J.A.M. 2003. Grapevine root distribution in drip and microsprinkler irrigation. Scientia Agricola 60: 377-387.

Borges, A.L.; Oliveira, A.M.G. Nutrition, fertilization and liming. In: Cordeiro, Z.J.M. (Ed.). Banana production: technical aspects. Brasília: Embrapa, 2000. p 47 - 59. (In Portuguese). 
Ceccon, C.; Panzacchi, P.; Scandellari, F.; Prandi, L.; Ventura, M.; Russo, B.; Millard, P.; Tagliavini, M. 2011. Spatial and temporal effects of soil temperature and moisture and the relation to fine root density on root and soil respiration in a mature apple orchard. Plant and Soil 342: 195-206.

Clothier, B.E.; Green, S.R.1994. Rootzone processes and the efficient use of irrigation water. Agricultural Water Management 25: $1-12$.

Coelho, E.F.; Or, D. 1998. Root distribution and water uptake patterns of corn under surface and subsurface drip irrigation. Plant and Soil, 206: 123-136.

Doorembos, J.; Kassam, A.H. 1984. Efeito da água no rendimento das culturas = Yield response to water . UFPB, Campina Grande, PB, Brazil.

Fernandes, M.F.; Barreto, A.C.; Mendes, I. C.; Dick, R.P. 2011. Short-term response of physical and chemical aspects of soil quality of a kaolinitic Kandiudalfs to agricultural practices and its association with microbiological variables. Agriculture, Ecosystems and Environment 142: 419 - 427.

Green, S.R.; Kirkham, M.B.; Clothier, B.E. 2006. Root uptake and transpiration: from measurements and models to sustainable irrigation. Agricultural Water Management 86: 165-176.

Heimovaara, T.J.; Huisman, J.A.; Vrugt, J.A.; Bouten, W. 2004. Obtaining the spatial distribution of water content along a TDR probe using the SCEM-UA bayesian inverse modeling scheme. Vadose Zone Journal 3: 128-145.

Howell, T.A. 2001. Enhancing water use efficiency in irrigated agriculture. Agronomy Journal 93: 281-289.

Howell, T.A. 2008. Addressing the world water crisis. ASABE Resource Magazine 15: 5-8.

Hsiao, T.C.; Steduto, A.E.; Fereres, P.; Elias A.E. 2007. A systematic and quantitative approach to improve water use efficiency in agriculture. Irrigation Science 25: 209-231.

Hutmacher, R.B.; Nightingale, H.I.; Rolston, D.E.; Biggar, J.W.; Dale, F.; Vail, S.S.; Peter, D. 1994. Growth and yield responses of almond (Prunus amygdalus) to trickle irrigation. Irrigation Science 14: 117-126.

Hutton, R.J.; Loveys, B.R. 2011. A partial root zone drying irrigation strategy for citrus: effects on water use efficiency and fruit characteristics. Agricultural Water Management 98: 1485-1496.

IUSS (International Union of Soil Science). Working Group WRB. 2006. World reference base for soils resources. World Soil Resource Reports No. 103. FAO, Rome.

Jensen, C.R.; Battilani, A.; Plauborg, F.; Psarras G.; Chartzoulakis, K.; Janowiak, F.; Stikic, R.; Jovanovic, Z.; Li, G.; Qi, Xuebin.; Liu, F.; Jacobsen, S.E.; Andersen, M.N. 2010. Deficit irrigation based on drought tolerance and root signalling in potatoes and tomatoes. Agricultural Water Management 98: 403-413.

Ji, X.B., Kang, E.S., Chen, R.S., Zhao, W.Z., Zhang, Z.H., Jin, B.W.A. 2007. Mathematical model for simulating water balances in cropped sandy soil with conventional flood irrigation applied. Agricultural Water Management 87 (3), 337-346.
Jiménez-Martíneza, J., Skaggs, T.H., van Genuchten, M.Th., Candela, L. 2009. A root zone modelling approach to estimating groundwater recharge from irrigated areas. Journal Hydrology. 367 (1-2), 138-149.

Kaspar, T.C.; Ewing, R.P. 1997. Rootedge: Software for measuring root length from desktop scanner images. Agronomy Journal 89: 932-940.

Keller, J.; Bliesner, R.D. 1990. Sprinkle and Trickle Irrigation. Avibook, New York, NY, USA.

Koumanov, K.S.; Hopmans, J.W.; Schwankl, L.J.; Andreu, L.; Tuli, A. 1997. Application efficiency of micro-sprinkler irrigation of almond trees. Agricultural Water Management 34: 247-263.

Koumanov, K.S.; Hopmans, J.W.; Schwankl, L.J. 2006. Spatial and temporal distribution of root water uptake of an almond tree under microsprinkler irrigation. Irrigation Science 24: 267278.

Mubarak, I. Angulo-Jarmillo, R.; Mailhol, J.C.; Ruelle, P.; Khaledian, M.; Vauclin, M. 2010. Spatial analysis of soil surface hydraulic properties: Is infiltration method dependent? Agricultural Water Management, 97:1517-1526

Mmolawa, K.; Or, D. 2000. Root zone solute dynamics under drip irrigation: a review. Plant and Soil 222: 163-190.

Reichardt, K.; Timm, L.C. 2012. Soil, plant and atmosphere: concepts, processes and applications $=$ Solo, planta e atmosfera: Conceitos, processos e aplicações. 2. Ed. - Barueri, SP: Manole. (In Portuguese)

Silva, A.J.P.; Coelho, E.F.; Miranda, J.H.; Workman, S.R. 2009. Estimating water application efficiency for drip irrigation emitter patterns on banana. Pesquisa Agropecuária Brasileira 44: 730-737.

Selle, B.; Minasny, B.; Bethune, M.; Thayalakumaran, T.; Subhash, C. 2011. Applicability of Richard`s equation models to predict deep percolation under surface irrigation. Geoderma 160: 569578.

Skaggs, T.H., Shouse, P.J., Poss, J.A. 2006. Irrigating forage crops with saline waters: 2. Modeling root uptake and drainage. Vadose Zone Journal 5, 824-837,

Sobral, L.F.; Cintra, F.L.D.; Smyth, J.T. 2009. Lime and gypsum to improve root depth of orange crop in an Ultisol of the Coastal Tablelands. Revista Brasileira de Engenharia Agrícola e Ambiental 13: 836-839.

Souza, C.F.; Folegatti, M.V. 2010. Spatial and temporal characterization of water and solute distribution patterns. Scientia Agricola 67: 9-15.

Sophocleous, M. 2004.Global and regional water availability and demand: Prospects for the future. Natural Resources research 13: 61-75.

Xavier, F.A.S.; Tavares, R.C.; Marques, G.V.; Rodrigues, F.M.; Oliveira, T.S. 2012. Effect of localized irrigation on granulometry and chemical attributes of a Quartzipsamment soil cultivated with dwarf coconut. Ciência Agronômica 43: 5563 (in Portuguese, with abstract in English). 